\title{
The Effectiveness of Driver Education and Information Programs in the State of Nevada
}

\author{
Alexander Paz ${ }^{1}$, David Copeland ${ }^{2}$, Pankaj Maheshwari1, Kris Gunawan², \\ Mohammad Soroush Tafazzoli ${ }^{3}$ \\ ${ }^{1}$ Transportation Research Center, University of Nevada, Las Vegas, USA \\ ${ }^{2}$ Department of Psychology, University of Nevada, Las Vegas, USA \\ ${ }^{3}$ Department of Civil and Environmental Engineering, University of Nevada, Las Vegas, USA \\ Email: apaz@unlv.edu, david.copeland@unlv.edu, maheshwa@unlv.nevada.edu, kgunawan@unlv.nevada.edu, \\ tafazzol@unlv.nevada.edu
}

Received 27 November 2014; accepted 11 December 2014; published 13 January 2015

Copyright (C) 2015 by authors and Scientific Research Publishing Inc.

This work is licensed under the Creative Commons Attribution International License (CC BY).

http://creativecommons.org/licenses/by/4.0/

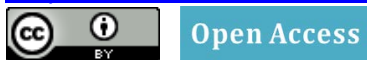

\section{Abstract}

According to National Highway Traffic Safety Administration, pedestrian and driver crashes are increasing at an alarming rate due to technological advancements and human errors. There is a need to improve existing driver education programs to mitigate the chances of crashes. The objectives of this research were 1) to examine the quality of Nevada's driver education by evaluating the effectiveness of its programs, and 2) to provide recommendations to improve driving education in Nevada based on the results from this study. Two different surveys were conducted in Clark County, Southern Nevada. The first survey focused on assessing the strengths and limitations of the current Driver Education Programs in Nevada by capturing the opinions and attitudes of those who went through the process as teenagers. The second survey focused on driver safety through the involvement of pedestrians on the road. These surveys and the corresponding statistical analysis as well as the exiting literature have provided insights to improve driving education. The corresponding recommendations were organized into seven major categories: 1) lack of rigor of online driver education, 2) interactive learning and technology, 3) follow-up exams, 4) practice/training at home, 5) collecting information about crashes, 6) pedestrians, and 7) additional emphasis. Finally, due to the dangers of driving distractions (texting and calling on the cell phone) and impairments (driving under the influence of alcohol or drugs), more emphasis on these topics-as well as more public announcements through billboards, television commercials, and magazinescan help to constantly remind drivers about having good driving habits.

\section{Keywords}

Driver Education, Driving Distractions, Interactive Learning Techniques, Statistical Analysis, Driver and Pedestrian Interactions 


\section{Introduction}

In a recent report by the National Highway Traffic Safety Administration (NHTSA) [1], 33,561 motor vehicle fatalities occurred nationally in year 2012, a 3.3\% increase overall from year 2011. In a similar analysis for 2012, the Insurance Institute for Highway Safety [2] reported that teenagers were involved in 8\% (2823 out of 33,561) of the total number of motor vehicle fatalities. Young drivers between 16 and 19 years old are nearly three times more likely than people over 20 years of age to have fatal vehicle crashes [2]. Traditionally driver education programs are considered successful if students meet learning objectives and pass tests, but driver education is expected to change subsequent behavior sufficiently to produce measurable effects on crashes [3]. Some research studies have found that graduates of driver education courses have fewer crashes and violations than their counterparts [4]. In addition, there are studies emphasizing the importance of driver education [5]. For example, Mayhew [6] has suggested that there are a number of strengths of driver education, including the controlled and safe environment in which novices can receive training. Similarly, driver education is considered "very important” for $86 \%$ of the respondents of a survey conducted in the U.S. [7].

A number of studies have been conducted in pertinent issues in young driver research, specifically the nuances in dealing with young driver licensing data. Foss [8] explained the techniques to improve structure of Graduated Driver Licensing (GDL) systems. Ferguson [9] examined the risk factors underlying teen's high crash rates and reviewed the existing GDL programs and discussed potential improvements. Dee et al. [10] analyzed whether restrictions such as adult supervision, daytime driving, and passenger limits have been effective in reducing traffic fatalities among teens. Their results indicated that GDL regulations reduced traffic fatalities among 15 - 17 years olds by at least 5.6\%. Shope [11] provided an overview of evaluation results of GDL since the year 2002. The results indicated that the GDL programs have reduced the youngest drivers' crash risk by roughly $20 \%$ to $40 \%$. Senserrick [12] provided recent developments in young driver education, training and licensing in Australia and recommended increased supervision, delayed licensure, and passenger and nighttime restrictions on provisional licenses. Twisk and Stacey [13] reviewed European trends regarding teen drivers' accident risk and the effects of countermeasures; and suggested multiphase licensing systems, accompanied driving, protective measures, and probation periods as methods to reduce accident risk.

The purpose of the driver education program is to promote safety for inexperienced drivers, especially teens. This program is associated with the GDL system, implemented in year 2005 in Nevada [14]. The GDL system adds more driving restrictions to teenage drivers under the age of 18. In California, fatal and severe injury crash rates were reduced for 16- and 17-year-old drivers after the state implemented a stricter GDL program in year 1998 [15]. Similarly, other states have shown a decrease in the number of vehicle crashes for teenage drivers when implementing their own restricted driver program [16] [17].

Although driver education programs provide some benefits making young drivers more aware about safe driving, improvements still are needed to enhance driver safety and reduce the chances of fatalities involving young drivers. With the availability and accessibility of driver education in the U.S., more teenagers are likely to get their driver license early; this trend could lead to more crashes [18]. Clinton and Lonero [19] argued that having young and novice drivers go through a driving course does not necessarily reduce the risk of crashes; other factors must be considered when examining driver education.

According to the Nevada Department of Transportation (NDOT) [20], Nevada ranks among the top 10 for the highest crash rates in the United States. Some of the factors contributing to these crash cases were failing to stay in the proper lane, speeding, drinking, falling asleep, and using drugs. In 2010, Nevada sustained a \$1.809 billion loss due to crashes. In 2006, the NDOT, the Nevada Department of Public Safety, and other safety agencies began an aggressive safety program, the Nevada Strategic Highway Safety Plan [21]. This plan includes a Zero Fatalities campaign started in 2010 to promote safe driving and to eliminate or reduce the possible chance of losing more lives from car crashes. Although this program may not be the only contributing factor in creating safer drivers, reports have shown that between 2006 and 2012, traffic fatalities went from 431 to 258, about a $59.9 \%$ reduction [22].

Further actions are required to continue this downward trend for fatalities and injuries caused by drivers in Nevada. In fact, findings have shown that male and female drivers between the age group of 26 and 35 are prone to causing more vehicle crashes than the younger age groups in Nevada [20]. Based on the driving exposure, older drivers tend to driver more often than young drivers, which may explain their higher crash rates. Therefore, more research is needed to determine whether such programs as driver education courses and the GDL system are effective in the long term. 
The purpose of this research was to examine the effectiveness of driver education and information programs in the State of Nevada. The results from this paper were used to provide recommendations and suggestions for ways to enhance the current driver education system as well as driver safety. The following objectives were addressed: a) Effectiveness of current driver education programs in Nevada, b) Data collection regarding driver and pedestrian safety in Nevada, c) Development of mechanisms to educate and inform Nevada drivers and pedestrians about traffic safety, and d) Development of simple yet innovative tools to train drivers about driver safety.

The paper is organized as follows. Section 2 provides the methodology and data required to conduct the surveys. Results and analysis are presented in Section 3. Recommendations for improving driver education and pedestrian knowledge are discussed in Section 4. The overall conclusions and findings are described in Section 5.

\section{Methodology}

This section describes the survey and analysis approach. A survey on the effectiveness of driver's education program is discussed in Section 2.1. Section 2.2 discusses a survey on the driver experience and knowledge whereas Section 2.3 discusses separate survey on driver and pedestrian safety.

\subsection{A Survey on the Effectiveness of Driver Education}

A survey was designed and conducted to examine the effectives of Driver Education Programs in Nevada. Although studies about the Driver Education Programs and GDL Systems have shown benefits for teenage drivers who still are teenagers, the findings are limited only to that particular age group. More of a challenge is tracking those who are now in college, or beyond 18 years of age, on whether the safety habits and skills that they learned in driver training have been effective over time. This survey attempted to evaluate and provide insights about this issue.

A total of 330 people participated in this survey, all living within Clark County in Southern Nevada. It was a pen and paper (offline) survey and a convenience sampling technique was used to conduct the survey. The sample was taken from a college population at the main campus of the University of Nevada, Las Vegas (UNLV). Of this group, 225 were Las Vegas residents, 62 were Henderson residents, 35 were North Las Vegas residents, seven were from Boulder City, and one was from Pahrump. The sample consisted of 108 males and 222 females, with an average age of 20.54 years, Standard Deviation (SD) $=4.309$ years. Of those who held a vehicle document in the sample, 35 were out-of-state licenses, 268 were Nevada driver licenses, and 27 were Nevada instruction permits. In addition, all the participants had completed their driver's education course within the past eight years to avoid any recall bias; i.e. the study ensures the accuracy of information by participants regarding past experiences.

\subsection{A Survey on the Driver Experience and Knowledge}

\subsubsection{Driver Experience}

For the following analyses, 268 people with Nevada driver licenses were included. The general focus was to examine some of their driving habits and skills. A multiple regression analysis was conducted to determine whether the following variables were associated with the likelihood of vehicle accidents:

- The number of years a person has had experience driving (Driver Experience),

- Current age (Age),

- The number of close calls or near accidents (Close Calls),

- The number of times being pulled over (Pulled Over),

- The number of police warnings (Warnings), and

- The number of times a person has received a police ticket (Ticket).

One of the participants was excluded from the analysis because his/her response was incomplete. For this multiple regression model, 267 responses were analyzed.

\subsubsection{Driver Knowledge}

This section discusses about the driver's knowledge regarding driving laws in Nevada. The ratings of the respondents' confidence ranged from " 1 " (extremely confident that there is no law) to " 7 " (extremely confident 
that there is a law). The following questions were asked to test driver's knowledge about the laws in Nevada.

- Using hand-held phones while driving,

- Driving under the influence of alcohol,

- Using hands-free cell phones while driving,

- Driving under the influence of prescription drugs, and

- Driving under the influence of recreational drugs.

\subsection{A Survey on Driver and Pedestrian Safety}

The NHTSA [23] reported that between 2011 and 2012, the number of pedestrian fatalities and injuries in the United States significantly increased to $6.4 \%$ (from 4457 to 4743 ) and 10\% (from 69,000 to 76,000), respectively, due to traffic crashes. According to the Nevada Strategic Highway Safety Plan [24], Nevada faces unique issues regarding pedestrians involved in traffic crashes. Between 2007 and 2011, 227 pedestrian fatalities and 881 injuries occurred. These problems - both nationally and in the State of Nevada - demonstrate the urgent need to provide information and education regarding safety on the roads. Solutions must focus not only on drivers but also on the pedestrians who share the road with them.

The aim of this survey was to examine the opinions and attitudes of drivers and pedestrians about the quality and safety of the traffic environment in Nevada. The survey focused on: a) The effectiveness of the crosswalks, b) The attention and respect that drivers and pedestrians give to each other, and c) The assessment of the current laws and penalties given for violations made by drivers and pedestrians.

A total of 148 randomly selected people volunteered to take part in the survey. From this group, 107 residents were from Las Vegas, 39 from Henderson, and two from North Las Vegas. Of these volunteers, 65 were males and 83 were females. They ranged from 18 to 68 years of age with a mean age average of 25.84 years and a standard deviation of 8.647 years. Four people chose not to respond to question regarding age. From those taking the survey, 138 responded "yes" to being able to drive and 8 responded 'no' to not being able to drive.

\section{Results and Analysis}

This section presents the results and analysis of three surveys described in Section 2.1, Section 2.2 and Section 2.3 respectively. Section 3.1 provides the results of survey based on Effectiveness of Driver Education. Section 3.2 summarizes the results of survey based on Driver Experience and Knowledge whereas Section 3.3 illustrates the results of survey based on Driver and Pedestrian Safety.

\subsection{Results of Survey Based on Effectiveness of Driver Education}

A total of 166 out of the 268 people received their licenses before the age of 18 in Nevada. They were asked several questions about going through the Driver Education Program.

Question 1 asked about the place to obtain their Certificate of Completion. The online course was the most popular for those who went through the Driver Education Program to obtain their Certificate of Completion ( $\mathrm{n}=$ 75). The second largest group was those who went through their driver education at their high school $(n=60)$. The rest either took it at a professional driving school certified by the Nevada Department of Motor Vehicles ( $\mathrm{n}=$ $26)$ or did not give a response to the question $(n=5)$.

Question 2 corresponds to rating the effectiveness of the Driver Education Program from " 1 " being very ineffective and "5" being very effective. On average, people responded to "teaching skills to drive in a vehicle" as neither ineffective nor effective $(M=3, S D=1.301)$. People rated as somewhat effective $(M=4.25, S D=0.795)$ "teaching the traffic rules and laws". Regarding "teaching how to deal with hazardous conditions", they rated that as neither ineffective nor effective $(M=3.47, S D=1.095)$. For "teaching how to purchase a vehicle", they gave an average rating of somewhat ineffective $(\mathrm{M}=1.59, \mathrm{SD}=1.029)$. Lastly, for "teaching the process of obtaining a driver license", the rating was neither ineffective nor effective $(\mathrm{M}=3.4, \mathrm{SD}=1.258)$.

Question 3 dealt with how well certain topics were covered in the training on a scale from 1 (Not Covered At All) to 5 (Covered Extremely Well). The topics that were covered extremely to fairly well were about the traffic rules and laws $(\mathrm{M}=4.16, \mathrm{SD}=0.958)$ as well as about being a considerate and safe driver $(\mathrm{M}=3.61, \mathrm{SD}=$ 1.141). The topics that were covered moderately to slightly well were a) Knowing how to deal with risky conditions $(\mathrm{M}=3.49, \mathrm{SD}=1.152)$, b) Avoiding and dealing with distractions while driving $(\mathrm{M}=3.43, \mathrm{SD}=1.270)$, $\mathrm{c})$ 
Controlling negative emotions while driving $(\mathrm{M}=2.82$, $\mathrm{SD}=1.297)$, and d) Planning a driving route ahead of time $(\mathrm{M}=2.51, \mathrm{SD}=1.339)$.

Question 4 enquired whether they were taught about the distractions that can affect driving. The four highly selected types of distraction that driver education programs taught the students well were driving under the influence (87.95\%), dealing with weather (86.14\%), texting on their cell phone (85.54\%), and handling passengers in a vehicle (85.54\%). The four types of distraction taught least were grooming and doing make-up (50.00\%), eating (54.22\%), dealing with environmental factors (63.25\%), and driving under the influence of other drugs besides alcohol (81.93\%).

Question 5 asked how much safety did motivated their driving habits and behaviors after completion of training. The results showed that about $82.5 \%$ of those who took part in the Nevada Driver Education Program reported that their motivation to have safe driving habits and behaviors were moderately important $(n=17)$, an important influence $(n=70)$, or a top priority $(n=50)$. This finding demonstrated that taking a course in driver education could increase their motivation level for safety.

Question 6 asked if they had to take a driver education training again, would they prefer an online or in-person class. The results showed that about $52.40 \%$ (87/166) of the sample preferred to retake their driver training in person. In other words, while people took driver education online, they acknowledged that may be they should have taken it in person.

Question 7 asked about rating the difficulty of their training. About $71.1 \%(118 / 166)$ rated their driver education training as either somewhat easy $(n=24)$, easy $(n=34)$, or very easy $(n=60)$. The ratings are very informative in that they indicate that the Driver Education Programs in Nevada are not as rigorous or challenging as needed. This is a potentially serious concern because better learning typically is associated with higher levels of effort [25] [26].

Question 8 asked about the satisfaction level with learning how to drive. Regarding their ability to learn to drive, 51.8\% (86/166) rated "somewhat satisfied" $(n=31)$, "satisfied” $(n=38)$, or "very satisfied" $(n=17)$. Out of 166 people, 35 (21.1\%) had a neutral stance regarding their satisfaction; 26 (15.7\%) were 'somewhat dissatisfied' ( $n=17)$, “dissatisfied" $(n=5)$, or "very dissatisfied" $(n=4)$; and $19(11.4 \%)$ gave no response to this question.

Question 9 asked if they could practice using a driving simulator (i.e., a virtual reality driving machine), would they use it for the behind-the-wheel experience. About half of the people in the sample (94/166 people; $56.6 \%)$ responded by saying that they would probably $(n=55)$ or definitely $(n=39)$ practice their driving through a simulator, 32 (19\%) did not know whether they would be interested in the driving simulator, and 40 (24.1\%) responded that they probably or definitely would not be interested in using the driving simulator.

Question 10 asked about the changes that would make them better drivers. The top four selected changes that people thought would improve the quality of driver education were using a driving simulator to practice driving (53.01\%), improving the teaching methods in the classes (46.39\%), and requiring an exit exam to graduate from the program (37.35\%). Tied for fourth was extending the number of required driving hours with an instructor (36.14\%) and taking an annual driving exam for X number of years after earning their license (36.14\%).

\subsection{Results of Survey Based on Driver Experience and Knowledge}

\subsubsection{Driver Experience}

The results of the survey based on driver experience are shown below. A multiple regression model was used to conduct the analysis. For this multiple regression model, 267 responses were analyzed. Descriptions of the predictor and outcome variables are shown in Table 1(a). The findings indicated a significant multiple regression, $F(6,260)=7.510, p<0.001$, when entering the explanatory variables to estimate the outcome variable (Accidents). Table 1(b) shows that based on the R-squared value, only $14.8 \%$ of the variability of the predictors could account for the likelihood of drivers getting into accidents. The results of each predictor are shown as follows. Interpretation of each predictor variable is true only if the other predictors are held constant. The B represents unstandardized beta coefficients, reflecting on the directionality of the predictive relationships.

Driver Experience: When a person has fewer years of driving experience, they are likely to get into more vehicle accidents ( $\mathrm{B}=-0.065), \mathrm{t}(266)=-2.847, \mathrm{p}<0.01$.

Age: As age increases, the number of vehicle accidents also increases $(B=0.058), t(266)=2.926, p<0.01$. Although it may seem odd that age and driver experience do not show a similar prediction, the sample consisted 
Table 1. Descriptive Statistics.

(a) Description of Variables

\begin{tabular}{ccccc}
\hline Predictor Variables & $\boldsymbol{M}$ & $\boldsymbol{S D}$ & Minimum & Maximum \\
\hline Driver Experience & 3.03 years & 3.744 years & 0 years & 29 years \\
Age & 20.69 years & 4.419 years & 17 years & 45 years \\
Close Calls & 3.61 & 5.851 & 0 & 50 \\
Pulled Over & 1.25 & 2.269 & 0 & 0 \\
Warnings & 0.6 & 1.42 & 0 & 14 \\
Tickets & 0.65 & 1.399 & Minimum & Maximum \\
\hline Outcome Variable & $\boldsymbol{M}$ & 0.833 & 0 & 5 \\
Accidents & 0.51 & $S D=$ Standard Deviation &
\end{tabular}

(b) Multiple Regression

\begin{tabular}{ccc}
\hline Predictors & $\boldsymbol{B}$ & SE B \\
\hline Constant $^{*}$ Driver Experience $^{*}$ & -0.63 & 0.352 \\
Age $^{*}$ & -0.065 & 0.023 \\
Close Calls $^{*}$ & 0.058 & 0.02 \\
Pulled Over $^{*}$ & 0.003 & 0.009 \\
Warnings & 0.177 & 0.048 \\
Tickets & -0.092 & 0.052 \\
\hline
\end{tabular}

R-squared $=14.8 \%$ B $=$ Unstandardized Beta Coefficients, ${ }^{*} \mathrm{p}<0.05, \mathrm{SE} \mathrm{B}=$ Standard Error.

of those who may have received their Nevada driver license at an older age, hence, giving them less overall experience.

Close Calls: The number of close calls or near accidents did not significantly contribute to the model for predicting the number of vehicle accidents, $\mathrm{t}(266)=0.348, \mathrm{p}=0.728$.

Pulled Over: As people get pulled over in greater numbers by the police, there is an increased likelihood that they also would get into vehicle accidents $(\mathrm{B}=0.177), \mathrm{t}(266)=3.702, \mathrm{p}<0.001$. Being pulled over may be a sign of people's aggressive driving behavior, which may contribute to vehicle accidents.

Warnings: There was no significance in predicting the number of vehicle accidents with the number of police warnings, $\mathrm{t}(266)=-1.784, \mathrm{p}>0.05$.

Tickets: The number of police tickets did not significantly predict the likelihood of getting into accidents, $\mathrm{t}$ $(266)=-0.970, \mathrm{p}=0.333$.

The regression model shown in Table 1(b) indicates that driver experience, age, and being pulled over all were predictive of vehicle accidents. However, due to a limited sample, these findings may only be predictive to those in this survey. As noted earlier, only $14.8 \%$ of the variance could be accounted for between the predictor variables and the number of vehicle accidents. Even so, it may be possible that the number of close calls, police warnings, and police tickets can affect people's behavior regarding getting into vehicle accidents. Further research is needed by increasing the sample size in order to determine whether the predictors are likely to influence vehicle accidents.

Other analyses were conducted based on survey questions about their driving habits and experiences. Question 1 asked whether they ever committed any violations while driving even if they did not get a ticket or warning for it. The results indicated that the three top violations committed were driving over the speed limit (81.34\%), talking on the cell phone while driving (55.60\%), and texting while driving (51.49\%). Question 2 asked how frequently they use their cell phone without a headset while driving. The results showed that $75 \%$ 
(201/268) use their cell phones without a headset while driving (which is illegal). Question 3 asked how frequently do they text on their cell phone while driving. A significant number of respondents (81\%; 217/268) stated that they texted while driving (which is illegal). Question 4 asked if they text on their cell phone while driving, when do they do the texting. The results showed that $78.36 \%$ (210/268) people text when they stop at a traffic stop and 8.96\% (24/268) pull over and text. However, 18.28\% (49/268) admitted to texting while driving the vehicle. Question 5 asked whether they had ever driven under the influence of alcohol. Out of the 268 people in this sample, 22.80\% (61/268) had driven under the influence of alcohol and 77.20\% (207/268) had not. While $22 \%$ still is high, it should be noted that these values were much lower than the percentages of people who reported texting or using a cell phone without a headset. The high cell phone and texting numbers were especially alarming because psychological research had shown comparable negative effects for both cell phones as well as intoxication on driving [27]. Question 6 asked whether they had ever driven under the influence of other drugs (e.g., prescribed or recreational drugs). The results indicated that $14.20 \%$ (38/268) people had driven under influence of other drugs whereas 85.80\% (230/268) people had never done drugs while driving. Question 7 asked whether they had ever driven while being close to falling asleep. The results showed that $64.60 \%(173 / 268)$ people had driven while close to falling asleep.

\subsubsection{Driver Knowledge}

The results of the survey based on driver knowledge are shown below. When asked how confident they were about the laws in Nevada, on average, people were confident to extremely confident that there were laws against the following (Table 2):

- Using hand-held phones while driving $(M$ rating $=6.58, S D=1.111)$,

- Driving under the influence of alcohol $(M$ rating $=6.83, S D=0.900)$,

- Driving under the influence of prescription drugs ( $M$ rating $=5.60, S D=1.736)$, and

- Driving under the influence of recreational drugs ( $M$ rating $=6.71, S D=0.989$ ).

In addition, on average, they were confident that there was no law regarding using hands-free cell phones while driving $(M$ rating $=2.51, S D=1.712)$.

Table 2. Confidence Levels Regarding Driving Laws in Nevada.

\begin{tabular}{|c|c|c|c|c|c|c|c|c|c|c|}
\hline \multirow{2}{*}{$\begin{array}{l}\text { Is there a law in } \\
\text { Nevada that... } \\
\text { Ratings }\end{array}$} & \multicolumn{2}{|c|}{$\begin{array}{c}\text {... bans the use } \\
\text { of hand-held cell } \\
\text { phones while } \\
\text { driving? }\end{array}$} & \multicolumn{2}{|c|}{$\begin{array}{l}\text {... bans the use } \\
\text { of hands-free } \\
\text { cell phones } \\
\text { while driving? }\end{array}$} & \multicolumn{2}{|c|}{$\begin{array}{l}\text {... prohibits } \\
\text { driving under } \\
\text { the influence } \\
\text { of alcohol? }\end{array}$} & \multicolumn{2}{|c|}{$\begin{array}{l}\text {... prohibits driving under the } \\
\text { influence of prescription drugs } \\
\text { (e.g., painkillers, allergy } \\
\text { medications, sleep aids, etc.)? }\end{array}$} & \multicolumn{2}{|c|}{$\begin{array}{c}\text {... prohibits driving } \\
\text { under the influence } \\
\text { of illegal drugs (e.g., } \\
\text { marijuana, heroin, etc.)? }\end{array}$} \\
\hline & $n$ & $\%$ & $n$ & $\%$ & $n$ & $\%$ & $n$ & $\%$ & $n$ & $\%$ \\
\hline $\begin{array}{l}\text { 1) Extremely } \\
\text { confident that } \\
\text { there is no law }\end{array}$ & 5 & $1.87 \%$ & 103 & $38.43 \%$ & 5 & $1.87 \%$ & 7 & $2.61 \%$ & 4 & $1.49 \%$ \\
\hline $\begin{array}{l}\text { 2) Confident that } \\
\text { there is no law }\end{array}$ & 2 & $0.75 \%$ & 64 & $23.88 \%$ & 1 & $0.37 \%$ & 15 & $5.60 \%$ & 1 & $0.37 \%$ \\
\hline $\begin{array}{l}\text { 3) Somewhat } \\
\text { confident that } \\
\text { there is no law }\end{array}$ & 2 & $0.75 \%$ & 31 & $11.57 \%$ & 0 & $0.00 \%$ & 16 & $5.97 \%$ & 1 & $0.37 \%$ \\
\hline 4) Unsure & 6 & $2.24 \%$ & 38 & $14.18 \%$ & 1 & $0.37 \%$ & 31 & $11.57 \%$ & 7 & $2.61 \%$ \\
\hline $\begin{array}{l}\text { 5) Somewhat } \\
\text { confident that } \\
\text { there is a law }\end{array}$ & 7 & $2.61 \%$ & 9 & $3.36 \%$ & 1 & $0.37 \%$ & 34 & $12.69 \%$ & 6 & $2.24 \%$ \\
\hline $\begin{array}{l}\text { 6) Confident } \\
\text { there is a law }\end{array}$ & 33 & $12.31 \%$ & 10 & $3.73 \%$ & 6 & $2.24 \%$ & 34 & $12.69 \%$ & 12 & $4.48 \%$ \\
\hline $\begin{array}{l}\text { 7) Extremely } \\
\text { confident that } \\
\text { there is a law }\end{array}$ & 213 & $79.48 \%$ & 13 & $4.85 \%$ & 254 & $94.78 \%$ & 131 & $48.88 \%$ & 237 & $88.43 \%$ \\
\hline Total $N$ & 268 & & 268 & & 268 & & 268 & & 268 & \\
\hline $\begin{array}{l}\text { Mean Rating } \\
\text { Response }\end{array}$ & 6.58 & & 2.51 & & 6.83 & & 5.6 & & 6.71 & \\
\hline$S D$ & 1.111 & & 1.712 & & 0.9 & & 1.736 & & 0.989 & \\
\hline
\end{tabular}

$n=$ number of responses; $N=$ total responses; $S D=$ standard deviation. 


\subsection{Results of Survey Based on Driver and Pedestrian Safety}

The survey questions consisted of a Likert-type response [28], with only five choices for each question. In order to determine people's opinions and attitudes, these choice/rating responses corresponded to a certain number. To conduct the statistical analysis, a one-sample t-test was used to determine whether the sample means were statistically different from the criterion value; in this case, "3" represented a neutral response (impartial). People who did not give any response to a question were excluded from the analysis. The findings showed no sex differences $(p>0.05)$ in the responses for each question; therefore, the questions were analyzed as an entire group. The results from the survey questions are shown in Table 3.

The results for Question 1 indicated that people rated the crosswalks in Nevada as being somewhat effective, $\mathrm{t}$ $(144)=6.762, p<0.001$. The mean score for their rating responses was at 3.43. The response to Question 2 indicated that although there was only a marginal statistical significance for their responses about how attentive drivers were to pedestrians crossing the street, $\mathrm{t}(144)=-1.625, \mathrm{p}=0.106$, the patterns appear split between people who say that drivers were inattentive and people who had no opinion at all. The mean score for their rating responses was 2.89. The results for Question 3 indicated that there was no statistical difference in response for people's attitudes about the safety of crossing at a crosswalk, t $(144)=1.178, \mathrm{p}=0.241$. People felt neither unsafe nor safe $(M=3.08)$. The results to Question 4 indicated a marginally significant difference in people's response about the respect drivers give to pedestrians when crossing the street, $t(144)=-1.608, p=0.110$. The mean score for their rating responses was 2.88. For Question 5, the results indicated that there was no significant

Table 3. Survey questionnaire on driver and pedestrian safety.

\begin{tabular}{|c|c|c|c|c|c|c|c|c|c|c|c|c|}
\hline \multirow{2}{*}{$\begin{array}{l}\text { Ratings } \\
\text { Questions }\end{array}$} & \multicolumn{2}{|c|}{$\begin{array}{l}\text { 1) Very } \\
\text { Ineffective } \\
\text { 5) Very } \\
\text { Effective }\end{array}$} & \multicolumn{2}{|c|}{$\begin{array}{l}\text { 1) Very } \\
\text { Inattentive } \\
\text { 5) Very } \\
\text { Attentive }\end{array}$} & \multicolumn{2}{|c|}{$\begin{array}{l}\text { 1) Very } \\
\text { Unsafe } \\
\text { 5) Very Safe }\end{array}$} & \multicolumn{2}{|c|}{$\begin{array}{l}\text { 1) Very } \\
\text { Disrespectful } \\
\text { 5) Very } \\
\text { Respectful }\end{array}$} & \multicolumn{2}{|c|}{$\begin{array}{l}\text { 1) Never } \\
\text { 5) Always }\end{array}$} & \multicolumn{2}{|c|}{$\begin{array}{l}\text { 1) Strongly } \\
\text { Disagree } \\
\text { 5) Strongly } \\
\text { Agree }\end{array}$} \\
\hline & $M$ & $S D$ & $M$ & $S D$ & $M$ & $S D$ & $M$ & $S D$ & $M$ & $S D$ & $M$ & $S D$ \\
\hline $\begin{array}{l}\text { 1) How would you rate the } \\
\text { effectiveness of the crosswalks } \\
\text { (e.g., stop signals for people)? }\end{array}$ & 3.43 & 0.761 & & & & & & & & & & \\
\hline $\begin{array}{l}\text { 2) How would you rate how } \\
\text { attentive drivers are when } \\
\text { pedestrians cross the street? }\end{array}$ & & & 2.89 & 0.817 & & & & & & & & \\
\hline $\begin{array}{l}\text { 3) How safe do you feel when } \\
\text { crossing the crosswalk? }\end{array}$ & & & & & 3.08 & 0.846 & & & & & & \\
\hline $\begin{array}{l}\text { 4) How respectful do you feel } \\
\text { drivers are to pedestrians when } \\
\text { crossing the streets? }\end{array}$ & & & & & & & 2.88 & 0.878 & & & & \\
\hline $\begin{array}{l}\text { 5) How respectful do you feel } \\
\text { pedestrians are to drivers } \\
\text { on the streets? }\end{array}$ & & & & & & & 2.90 & 0.923 & & & & \\
\hline $\begin{array}{l}\text { 6) How often do you jaywalk (i.e., } \\
\text { cross the street in a non-designated } \\
\text { crosswalk?) }\end{array}$ & & & & & & & & & 2.34 & 0.966 & & \\
\hline $\begin{array}{l}\text { 7) Do you feel that the pedestrian } \\
\text { crossings need to be improved in } \\
\text { Nevada? }\end{array}$ & & & & & & & & & & & 3.80 & 0.847 \\
\hline $\begin{array}{l}\text { 8) Do you feel that there should be } \\
\text { a stricter law/penalty for drivers } \\
\text { passing the crosswalk when the } \\
\text { pedestrians have the right of way? }\end{array}$ & & & & & & & & & & & 3.66 & 0.930 \\
\hline $\begin{array}{l}\text { 9) Do you feel that there should } \\
\text { be a stricter law/penalty for } \\
\text { pedestrians who do not follow } \\
\text { the rules of crossing in designated } \\
\text { crosswalks (e.g., jaywalking)? }\end{array}$ & & & & & & & & & & & 3.78 & 0.975 \\
\hline
\end{tabular}

$M=$ mean; $S D=$ standard deviation. 
difference in people's responses about the respect pedestrians give to drivers, $t(144)=-1.260, p=0.210$. The mean score for their rating responses was 2.90, which indicated that pedestrians had "neither disrespectful nor respectful" attitudes about drivers on the street. The response to Question 6 indicated that pedestrians "rarely" jaywalked, $\mathrm{t}(144)=-8.251, \mathrm{p}=0.001$. The mean score for their rating responses was 2.34 . The results for Question 7 showed a significant difference in people's responses about whether they felt pedestrian crossings in Nevada needed to be improved, $\mathrm{t}(144)=11.379, \mathrm{p}=0.001$. The mean score for their rating responses was 3.80, indicating that more people agreed to have improvements made to the crosswalks. For Question 8, the results indicated that, people, on average, were more likely to agree that there should be a stricter law or penalty for drivers passing the crosswalk when the pedestrians had the right of way, $t(144)=8.576, p=0.001$. The mean score for their rating responses was 3.66. For Question 9, the analysis indicated that people agreed to the idea that there should be a stricter law or penalty for pedestrians who jaywalk and do not follow the rules for crossing, $\mathrm{t}(144)=9.623, \mathrm{p}=0.001$. The mean score for their rating was 3.78 .

\section{Recommendations}

This section proposes recommendations to make improvements in the existing driver education programs in the State of Nevada. The recommendations have been developed from:

- Results of the surveys conducted in this study, which clarifies the limitations and what efforts are needed.

- Assessment of randomly selected programs in Nevada for online driver education.

- Recommendations/conclusions in similar studies, particularly those that are conducted in the U.S.

It is important to note that the research literature on driver education and adolescents describes a number of factors that contribute to crashes that cannot be included in policy recommendations. For example, it has been determined that such factors as gender [29], personality [30], and socio-economic/education status [31] affect the likelihood of adolescent drivers being in a crash. However, because these types of factors cannot be included in testing, the corresponding policies or laws are not considered in this research. The following sections include recommendations that can be implemented to improve driver education and knowledge.

\subsection{Regarding Ease/Lack of Rigor of Online Driver Education}

- Make online driver education courses more challenging.

- Develop a more accurate assessment of the time spent completing topics. Time that currently is wasted can be filled with other learning activities.

- Use cognitive techniques [32] [33], such as frequent tests and cumulative tests.

- Avoid multiple-choice questions.

- Improve the validation process of who actually is completing the online course by means of technological fixes or by having the final exam given at a testing location.

\subsection{Regarding Interactive Learning and Technology}

- Rather than using online-only courses, create hybrid courses that require students to learn from an instructor.

- Another possibility is to use driving simulators in addition to the instructions received online (Figure 1).

- Convert online courses from passive learning to active learning by including animated activities.

The research team has begun developing various web-based interactive teaching modules to study and demonstrate the potential of this recommended method. Figure 2(a), Figure 2(b) and Figure 2(c) provide various screen shots for a prototype implementation.

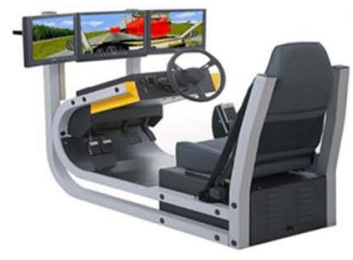

Driving in simulation by simulating the unsafe conditions for the drivers

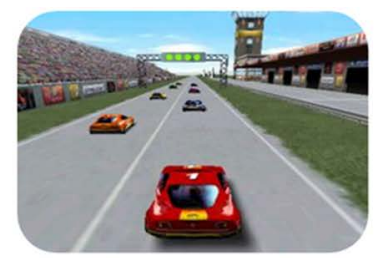

Designing video games with a focus on traffic signs and the quality to drive according to them

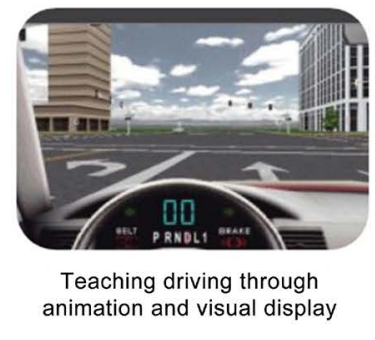

Teaching driving through
animation and visual display

Figure 1. An example of a driving simulator. 


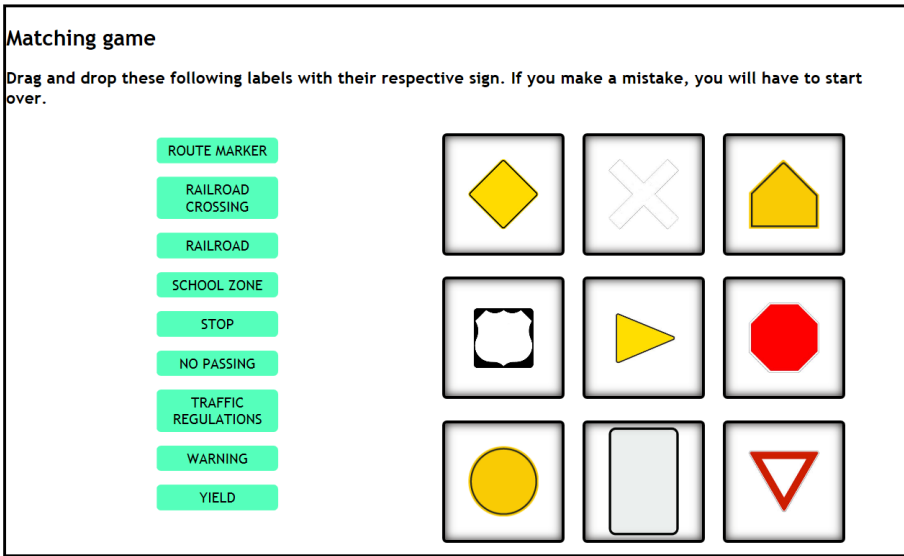

(a) Matching Game

\section{Stopping Distance and Time}

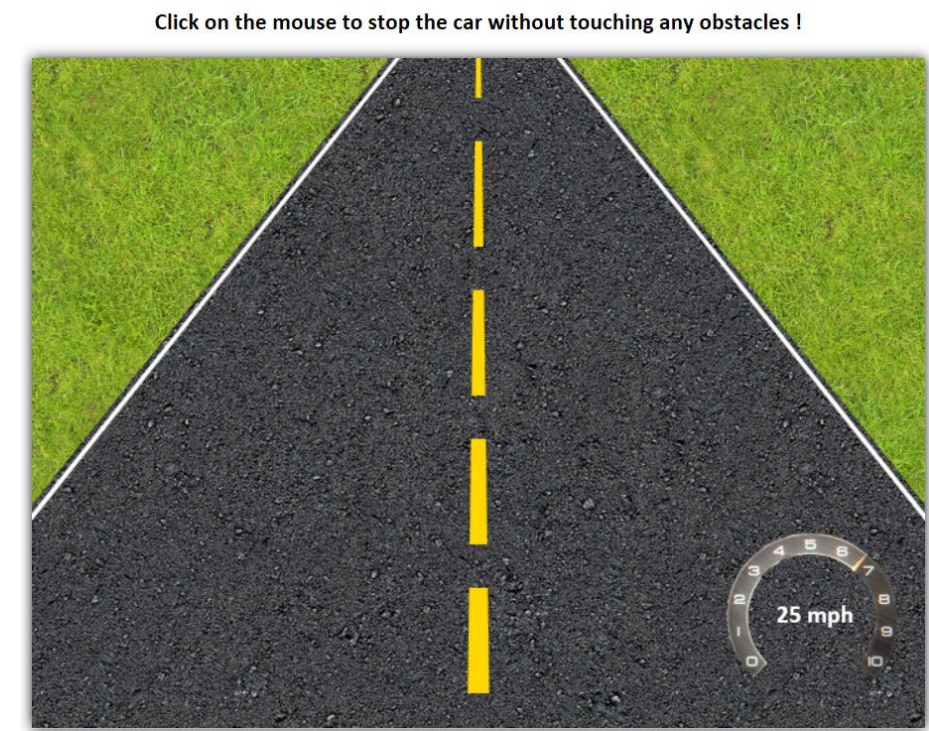

(b) Stopping Distance and Time

\section{Passing line}

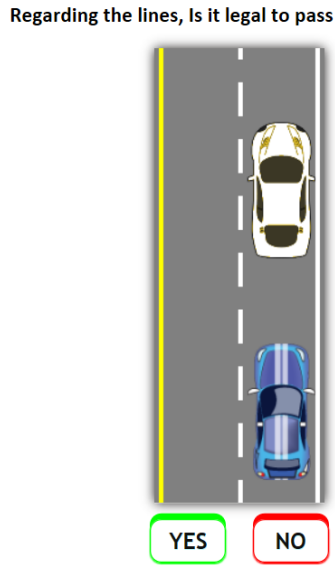

(c) Passing Lines

Figure 2. Prototype of web-based and interactive driving education tool. 


\subsection{Regarding Follow-Up Exams}

- Provide follow-up exams to make sure that people are currently aware of the driving laws and regulations before getting their driver licenses renewed.

- Restrict how many questions they can miss on the follow-up exam before getting their renewed license.

- Failure to pass the follow-up exam would result in people having to take the driver education course and repeating the same process of a new licensed driver.

\subsection{Regarding Practice and Training at Home}

- Instead of just requiring young drivers to complete a minimum number of hours, require the practice and completion of specific driving skills as well.

- Include an online tutorial for parents that refresh them on some important driving skills/rules. This will help ensure that they are passing on correct information to their child as they practice driving with them.

- Provide another option for driver education training, in which the parents or guardians are given a more active role in monitoring their teenager's learning [34].

\subsection{Regarding Collecting Information about Crashes}

- Retrieve more information about people's participation in a driver education program by having it recorded as part of a police report.

- Document people's driver education background when they apply for a driver license.

- Collaborate with insurance companies to examine the types of vehicle crashes [35] people commit between those who have taken and not taken a driver education course.

\subsection{Regarding Pedestrians}

- Through the driver education program, emphasize information about drivers and pedestrians sharing the road and being vigilant of each other's safety [36].

- Place more cautionary signs for pedestrians on the streets to remind them of their own safety.

- Improve the infrastructure of the streets by using more lighting near traffic signals or providing barriers to prevent people from illegally crossing the streets or drivers hitting them.

- Implement stricter laws for people who violate the driver or pedestrian rights of way by increasing the fines.

\subsection{Additional Emphasis}

- Continue and/or increase the emphasis on the dangers of driving under the influence of alcohol or drugs.

- Greatly increase the emphasis on the dangers of cell phone use and texting on driving. Drivers need to understand that cell phone use and texting can impair driving to similar extents as alcohol [27]. As mentioned earlier, demonstrations of these effects by using interactive applications may help.

- Address the dangers of distractions on the road through public announcements, such as billboards, television commercials, and magazines.

- Remind drivers about the penalties and fines involved for disobeying the law (e.g., texting while driving) by posting more signs on the road about them.

\section{Conclusions and Recommendations}

Nevada's Driver Education Program is an important tool to promote awareness of driver safety with the objective of reducing or eliminating the number of traffic fatalities and injuries in the state. Survey data reveal that some people seem to have acquired the necessary knowledge for driving safely; however, they do not use that knowledge. Therefore, the driver education program needs to have greater quality with regard to the learning process.

One of the biggest concerns is that the courses are not challenging enough for young drivers for them to realize adequately that driving is a privilege, not a right. More cumulative testing in these courses may have a beneficial effect to ensure that students remember what they learn in their driving courses. In addition, more interactions are needed, most preferably in person rather than online. With the use of technology, students can enhance 
their understanding of their driver education program. One way to do this is by incorporating driver simulators into the program so that they can experience firsthand various driving situations in a safe environment. Another way that might be less costly is to use interactive animations in an online course instead of relying heavily on text to learn the materials. Because drivers may forget over time the knowledge that they have learned from driver education, one recommendation is to provide follow-up exams. When they need to renew their driver license, they could be tested on the driving rules and regulations.

Although the driver education program focuses more on the driver, additionally, it may be beneficial to inform people about pedestrian safety. By emphasizing that drivers and pedestrians share the road equally, this awareness may help reduce the number of car accidents and injuries in Nevada. Further, by changing the infrastructure of the streets-adding more lighting near traffic signs at night, providing more warning signs for pedestrians, and building barriers to prevent people from jaywalking - this solution may help drivers and pedestrians avoid dangerous interactions. Finally, due to the dangers of driving distractions and impairments, more emphasis on these topics in driver education—as well as more public announcements can help to constantly remind drivers about having good driving habits.

\section{References}

[1] National Highway Traffic Safety Administration (2013) 2012 Motor Vehicle Crashes: Overview. http://www-nrd.nhtsa.dot.gov/Pubs/811856.pdf

[2] Insurance Institute for Highway Safety (2014) Teenagers: Driving Carries Extra Risk for Them. http://www.iihs.org/iihs/topics/t/teenagers/fatalityfacts/teenagers

[3] Lonero, L.P. (2008) Trends in Driver Education and Training. American Journal of Preventive Medicine, 35, S316S323. http://dx.doi.org/10.1016/j.amepre.2008.06.023

[4] Mayhew, D.R. (2007) Driver Education and Graduated Licensing in North America: Past, Present, and Future. Journal of Safety Research, 38, 229-235. http://dx.doi.org/10.1016/j.jsr.2007.03.001

[5] Mayhew, D.R. and Simpson, H.M. (1998) Effectiveness and Role of Driver Education and Training in a Graduated Licensing System. Journal of Public Health Policy, 19, 51-67. http://dx.doi.org/10.2307/3343089

[6] Mayhew, D.R. (2006) The Future of Driver Education. Driver Education: The Path Ahead, Transportation Research Circular, E-C101. Transportation Research Board, Washington DC.

[7] Williams, A.F. (2005) Commentary: Next Steps for Graduate Licensing. Traffic Injury Prevention, 6, 199-201. http://dx.doi.org/10.1080/15389580590969076

[8] Foss, R.D. (2007) Improving Graduated Driver Licensing Systems: A Conceptual Approach and Its Implications. Journal of Safety Research, 38, 185-192. http://dx.doi.org/10.1016/j.jsr.2007.02.006

[9] Deea, T.S., Grabowski, D.C. and Morrisey, M.A. (2005) Graduated Driver Licensing and Teen Traffic Fatalities. Journal of Health Economics, 24, 571-589. http://dx.doi.org/10.1016/j.jhealeco.2004.09.013

[10] Ferguson, S.A. (2003) Other High-Risk Factors for Young Drivers-How Graduated Licensing Does, Doesn’t, or Could Address Them. Journal of Safety Research, 34, 71-77. http://dx.doi.org/10.1016/S0022-4375(02)00082-8

[11] Shope, J.T. (2007) Graduated Driver Licensing: Review of Evaluation Results Since 2002. Journal of Safety Research, 38, 165-175. http://dx.doi.org/10.1016/j.jsr.2007.02.004

[12] Senserrick, T.M. (2007) Recent Developments in Young Driver Education, Training and Licensing in Australia. Journal of Safety Research, 38, 237-244. http://dx.doi.org/10.1016/j.jsr.2007.03.002

[13] Twisk, D.A.M. and Stacey, C. (2007) Trends in Young Driver Risk and Countermeasures in European Countries. Journal of Safety Research, 38, 245-257. http://dx.doi.org/10.1016/j.jsr.2007.03.006

[14] California State Automobile Association (2007) Nevada’s Graduated Driver Licensing. http://calstate.aaa.com/sites/default/files/bitcache/file/1c82797aba9c6434aab731e2c9cc366974ec6c46?vid=215826\&di sposition=inline\&op=view

[15] Rice, T.M., Peek-Asa, C. and Kraus, J.F. (2004) Effects of the California Graduated Driver Licensing Program. Journal of Safety Research, 35, 375-381. http://dx.doi.org/10.1016/j.jsr.2004.04.004

[16] Hyde, L.K., Cook, L.J., Knight, S. and Olson, L.M. (2005) Graduated Driver Licensing in Utah: Is It Effective? Annals of Emergency Medicine, 45, 147-154. http://dx.doi.org/10.1016/j.annemergmed.2004.10.007

[17] Vanlaar, W., Mayhew, D., Marcoux, K., Wets, G., Brijs, T. and Shope, J. (2009) An Evaluation of Graduated Driver Licensing Programs in North America: An Analysis of Relative Fatality Risks of 16, 17, 18, and 19 Year Old Drivers Using a Meta-Analytic Approach. N.P.: Traffic Injury Research Foundation. 
http://tirf.ca/publications/PDF_publications/GDL_meta_analysis_final_2009.pdf.

[18] Robertson, L.S. (1980) Crash Involvement of Teenaged Drivers When Driver Education Is Eliminated from High School. American Journal of Public Health, 68, 959-965. http://dx.doi.org/10.2105/AJPH.68.10.959

[19] Clinton, K. and Lonero, L. (2006) Guidelines for Evaluating Driver Education Programs. AAA Foundation for Traffic Safety, Washington DC.

[20] Nevada Department of Transportation (2010) Nevada Traffic Crashes 2010. http://www.zerofatalitiesnv.com/dld/2010\%20NEVADA\%20TRAFFIC\%20CRASH\%20BOOK.pdf

[21] Nevada Department of Transportation (2011) The 2011-2015 Nevada Strategic Highway Safety Plan. http://www.nevadadot.com/uploadedFiles/NDOT/About_NDOT/NDOT_Divisions/Planning/Safety_Engineering/2011 -2015_SHSP.pdf

[22] Nevada Department of Transportation (2014) Zero Fatalities: Drive Safe Nevada. http://www.zerofatalitiesnv.com/stats.php

[23] National Highway Traffic Safety Administration (2013) Distracted Driving 2011, 2013. http://www-nrd.nhtsa.dot.gov/Pubs/811737.pdf

[24] Nevada Department of Transportation (2013) Nevada's Pedestrian Safety Problem. http://www.zerofatalitiesnv.com/dld/Zero\%20Fatalities\%20Fact\%20Sheet\%20Pedestrian\%20Safety.pdf

[25] Craik, F.I.M. (2002) Levels of Processing: Past, Present, and...Future? Memory, 10, 305-318. http://dx.doi.org/10.1080/09658210244000135

[26] Craik, F.I.M. and Lockhart, R.S. (1972) Levels of Processing: A Framework for Memory Research. Journal of Verbal Learning and Verbal Behavior, 11, 671-684. http://dx.doi.org/10.1016/S0022-5371(72)80001-X

[27] Strayer, D.L., Drews, F.A. and Crouch, D.J. (2006) A Comparison of the Cell Phone Driver and the Drunk Driver. Human Factors, 48, 381-391. http://dx.doi.org/10.1518/001872006777724471

[28] Wyatt, R.C. and Meyers, L.S. (1987) Psychometric Properties of Four 5-Point Likert Type Response Scales. Educational and Psychological Measurement, 47, 27-35. http://dx.doi.org/10.1177/0013164487471003

[29] Williams, A.F. (2003) Teenage Drivers: Patterns of Risk. Journal of Safety Research, 34, 5-15. http://dx.doi.org/10.1016/S0022-4375(02)00075-0

[30] Lang, S.W., Waller, P.F. and Shope, J.T. (1996) Adolescent Driving: Characteristics Associated with Single-Vehicle and Injury Crashes. Journal of Safety Research, 27, 241-257. http://dx.doi.org/10.1016/S0022-4375(96)00028-X

[31] Bingham, C.R., Shope, J.T. and Tang, X. (2005) Drinking Behavior from High School to Young Adulthood: Differences by College Education. Alcoholism: Clinical and Experimental Research, 29, 2170-2180. http://dx.doi.org/10.1097/01.alc.0000191763.56873.c4

[32] Roediger III, H.L., Agarwal, P.K., Kang, S.H.K. and Marsh, E.J. (2010) Benefits of Testing Memory: Best Practices and Boundary Conditions. In: Davies, G.M. and Wright, D.B., Eds., New Frontiers in Applied Memory, Psychology Press, Brighton, 13-49.

[33] Roediger III, H.L. and Karpicke, J.D. (2006) The Power of Testing Memory: Basic Research Implications for Educational Practice. Perspectives on Psychological Science, 1, 181-210. http://dx.doi.org/10.1111/j.1745-6916.2006.00012.x

[34] Texas Department of Public Safety (2014) Parent Taught Driver Education (PTDE). http://www.txdps.state.tx.us/driverlicense/parenttaught.htm.

[35] Agarwal, S., Sancheti, A., Khaddar, R. and Kachroo, P. (2013) Geospatial Framework for Integration of Transportation Data Using Voronoi Diagrams. Transportation Research Board 92nd Annual Meeting, Washington DC, 13-17 January 2013, Paper No. 13-5378.

[36] Pulugurtha, S.S., Nambisan, S.S. and Maheshwari, P. (2006) Estimating Pedestrian Counts in Urban Areas for Transportation Planning and Safety Analyses. Applications of Advanced Technology in Transportation. The 9th International Conference, Chicago, 13-16 July 2006, 257-262. 
Scientific Research Publishing (SCIRP) is one of the largest Open Access journal publishers. It is currently publishing more than 200 open access, online, peer-reviewed journals covering a wide range of academic disciplines. SCIRP serves the worldwide academic communities and contributes to the progress and application of science with its publication.

Other selected journals from SCIRP are listed as below. Submit your manuscript to us via either submit@scirp.org or Online Submission Portal.
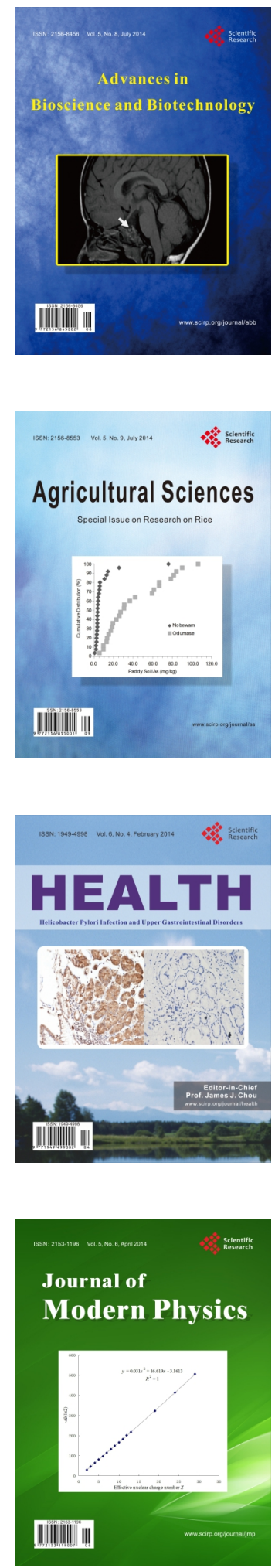
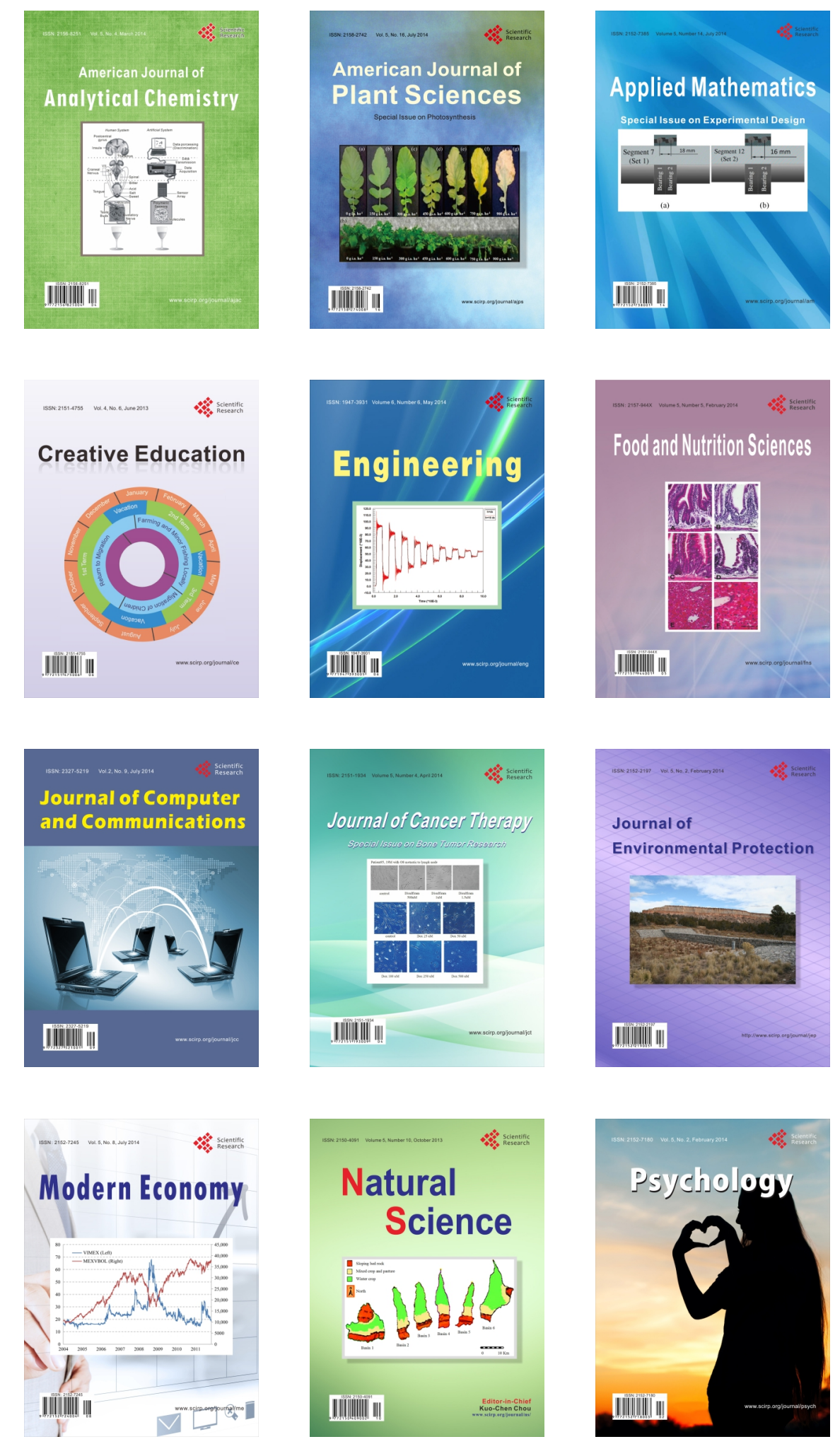